\title{
What's in a Name? A Candid Assessment of a New Candida Therapy
}

Karl Oláh (BJOG DEBATES ONLY) ${ }^{1}$

${ }^{1}$ Affiliation not available

October 6, 2021

\section{Hosted file}

Ibrexafungerp.doc available at https://authorea.com/users/439844/articles/540661-what-s-ina-name-a-candid-assessment-of-a-new-candida-therapy 